\title{
Acritarchs from the Buen Formation (Lower Cambrian), North Greenland
}

\author{
Gonzalo Vidal and John S. Peel
}

G. V., Micropalaeontological Laboratory, Box 124, Lund University, S-220 07 Lund, Sweden. J. S. P., Grønlands Geologiske Unders $\emptyset$ gelse, Øster Voldgade 10, DK-1350 København K, Denmark.

Siliciclastic sediments of the Buen Formation of North Greenland yield the earliest Cambrian fossils known from North Greenland, with the exception of cyanobacteria described from dolomites of the underlying Portfjeld Formation (see Peel, this report). The fauna is dominated by olenellid and nevadiid trilobites indicating an Early Cambrian age (Poulsen, 1974; Blaker, this report) but hyolithids, bradoriids, sponges and other fossils also occur. Bergström \& Peel (this report) described trace fossils from the Buen Formation. Of particular interest is the recent discovery of lightly skeletised arthropods comprising an assemblage similar to that of the Middle Cambrian Burgess shale of Canada (Conway Morris $e t$ al., 1987).

Fossiliferous black shales occurring near the middle of the formation at Jørgen Brønlund Fjord, southern Peary Land, near the type section of the formation, have been processed for acritarchs using methods described by Vidal (1976). The samples yield abundant, well preserved assemblages containing Comasphaeridium strigosum, Skiagia compressa, $S$. ornata type $1, S$. ornata type $2, S$. ciliosa type A, $S$. ciliosa type B, Goniosphaeridium varium, Baltisphaeridium dubium, B. cerinium, S. orbiculare, $S$. scottica, Micrhystridium tornatum, M. lanatum, M. dissimilare, Trachysphaeridium timofeevi, Tasmanites bobrowskae, T. tenellus, T. volkovae, Lophosphaeridium tentativum, Archaeodiscina umbonulata, Leiosphaeridia sp., Cymatiosphaera sp. and C. ?membranacea; they confirm the Early Cambrian age indicated by the macrofossils.

The acritarch assemblages from the Buen Formation are evidently similar to assemblages from the Bastion Formation of East Greenland described by Downie (1982) and Vidal \& Peel (1984; Moczydlowska \& Vidal, 1986). They closely resemble upper Lower Cambrian assemblages from Scandinavia and the eastern part of the European Platform (Vidal, 1981; Moczydlowska \& Vidal, 1986).

Conway Morris, S., Peel, J. S., Higgins, A. K., Soper, N. J. \& Davis, N. C. 1987: A Burgess shale-like fauna from the Lower Cambrian of North Greenland. Nature 326, 181-183.

Downie, C. 1982: Lower Cambrian acritarchs from Scotland, Norway, Greenland and Canada. Trans Roy. Soc. Edinburgh, Earth Sci. 72, 257-285.

Moczydlowska, M. \& Vidal, G. 1986: Lower Cambrian acritarch zonation in southern Scandinavia and southeastern Poland. Geol. För. i Stockholm Förhandl. 108, 201-223.

Poulsen, V. 1974: Olenellacean trilobites from eastern North Greenland. Bull. geol. Soc. Denmark 23, 79-101.

Vidal, G. 1976: Late Precambrian microfossils from the Visingsö Beds in southern Sweden. Fossils and Strata 9, 57 pp.

Vidal, G. 1981: Micropalaeontology and biostratigraphy of the Lower Cambrian sequence in Scandinavia. U.S. Geol. Surv. Open-file Rept. 81-743, 232-235.

Vidal, G. \& Peel, J. S. 1984: Acritarch biostratigraphy of the Lower Cambrian of Greenland. In Armands, G. \& Schager, S. (edit.) Abstr. 16. Nord. Geol. Vintermötet Stockholm. Medd. Stockholm Univ. Geol. Inst. 255, 234 (only). 